\title{
Mainstreaming Biodiversity: Conservation for the Twenty-First Century
}

\begin{abstract}
Kent H. Redford ${ }^{1,2 *}$, Brian J. Huntley ${ }^{3}$, Dilys Roe ${ }^{4}$, Tom Hammond ${ }^{5}$, Mark Zimsky ${ }^{6}$, Thomas E. Lovejoy ${ }^{7}$, Gustavo A. B. da Fonseca ${ }^{6,8 *}$, Carlos M. Rodriguez ${ }^{9}$ and Richard M. Cowling ${ }^{10}$

${ }^{1}$ Archipelago Consulting, Portland, ME, USA, ${ }^{2}$ Department of Environmental Studies, University of New England, Biddeford, ME, USA, ${ }^{3}$ Centre for Invasion Biology, University of Stellenbosch, Stellenbosch, South Africa, ${ }^{4}$ International Institute for Environment and Development, London, UK, ${ }^{5}$ GEF Scientific and Technical Advisory Panel, Washington, DC, USA, ${ }^{6}$ Global Environment Facility, Washington, DC, USA, ${ }^{7}$ Department of Environmental Science and Policy, George Mason University, Fairfax, VA, USA, ${ }^{8}$ Department of Zoology, Universidade Federal de Minas Gerais, Belo Horizonte, Brazil, ${ }^{9}$ Conservation International, San Jose, Costa Rica, ${ }^{10}$ Department of Botany, Nelson Mandela Metropolitan University, Port Elizabeth, South Africa
\end{abstract}

Insufficient focused attention has been paid by the conservation community to conservation of biodiversity outside of protected areas. Biodiversity mainstreaming addresses this gap in global conservation practice by "embedding biodiversity considerations into policies, strategies and practices of key public and private actors that impact or rely on biodiversity, so that it is conserved, and sustainably used, both locally and globally" (Huntley and Redford, 2014). Biodiversity mainstreaming is designed to change those policies and practices that influence land uses outside of protected areas as well as to change economic and development decision-making by demonstrating the importance of conserving biodiversity for achieving development outcomes. The practice of mainstreaming is tied to implementation of the Convention on Biological Diversity and is practiced with billions of dollars of investment by development agencies, national government agencies, and the Global Environment Facility (GEF) and its implementing organizations as well as other donors. It is essential for the long-term survival of biodiversity inside and outside protected areas. However, it is virtually unheard of in the main conservation science field. This must change so as to bring careful documentation, analysis, monitoring, publishing, and improvement of practices-all things that conservation science should provide as partners to practitioners of biodiversity mainstreaming. The situation is ripe for informed coordination and consolidation and creation of a science-driven field of biodiversity mainstreaming.

Keywords: biodiversity, global environment facility, mainstreaming, production practices, protected areas

\section{INTRODUCTION}

Establishing and managing protected areas has long been a cornerstone of biodiversity conservation efforts and remains its most widely deployed and best-known strategy. The protected areas approach has been well studied from a variety of social, economic, and environmental perspectives and in the last few years has been extensively assessed for its effectiveness in delivering global biodiversity conservation targets (Geldmann et al., 2013; Watson et al., 2014). It is clear from 
such assessments that the current network of protected areas is insufficient to halt biodiversity loss globally (Butchart et al., 2010). Support for both increasing the effectiveness of existing protected areas as well as creating additional ones-as required by the Convention on Biological Diversity's Aichi Target 11- will require significantly increased backing from society; backing that will likely only come from demonstrating strong relationships between biodiversity conservation and human wellbeing (e.g., Stolton and Dudley, 2010). Even if the effectiveness of existing protected areas is increased and new ones are established there will always be a critical need to work outside the boundaries of protected areas as much of the earth's biodiversity is found in such settings.

What needs to be done in the lands and waters outside protected areas is the subject of considerable discussion and work by conservationists (c.f. Tscharntke et al., 2012). Though there have been important initiatives directed at work in these non-protected areas including ecological corridors and landscape approaches, it is our collective experience that these have not been sufficiently supported to achieve conservation objectives nor have they risen to the prominence they deserve. Because this work on conservation outside formally protected areas has not coalesced around common definitions, scope and work we conclude that it has been neither coherently pursued across multiple geographic and social settings nor effectively evaluated.

Meanwhile, beyond the conservation science community, as evidenced by the GEF-supported programs discussed below, there has been considerable activity in integrating biodiversity conservation into multiple use landscapes. This has resulted in a proliferation of approaches and tools for integrating biodiversity conservation into development or production sector policy and practice. Collectively these approaches are termed "biodiversity mainstreaming" - a process defined as "embedding biodiversity considerations into policies, strategies and practices of key public and private actors that impact or rely on biodiversity, so that it is conserved, and sustainably used, both locally and globally" (Huntley and Redford, 2014). Biodiversity mainstreaming is designed to change those practices that influence land uses outside of protected areas by demonstrating the importance of conserving biodiversity for achieving development outcomes (IIED and UNEP-WCMC, 2013). As such mainstreaming is a part of the larger effort to link biodiversity conservation and development funding and practice (Hicks et al., 2008; Miller, 2014). The concept of mainstreaming, if not the term itself, is gaining increasing credence and application but mainstreaming per se has not yet been seriously addressed by the conservation community in general, and the conservation science community in particular.

The Global Environment Facility (GEF), the financial mechanism for the Convention on Biological Diversity (CBD), is the world's largest funder of mainstreaming work within the conservation sector. Between 2004 and 2014 alone the GEF has supported 327 biodiversity mainstreaming projects with US $\$ 1.6$ billion in GEF funding and US\$5.2 billion in co-financing. In 2014 the GEF conducted a review of its mainstreaming portfolio (Huntley and Redford, 2014). This paper is rooted in that review and a previous one (Petersen and Huntley, 2005) and complemented by recent work in the field. The paper makes two major points:

1. Mainstreaming represents an important body of practice for conservation with very significant policy and funding support;

2. The role of mainstreaming is little known in conservation and its corpus of experience represents a rich body of work from which to learn and help in monitoring and improvement of existing practices and develop a science-driven field of biodiversity mainstreaming.

\section{TERMINOLOGY AND USERS}

"Mainstreaming" has been applied to a wide range of domains from music to politics. Its application to conservation and development has stemmed from the need to influence the ongoing practice of institutions that have considerable impact on the state of biodiversity with the values and practices of institutions that have the mandate to conserve and sustainably use biodiversity and who, in most countries, have historically had less political influence. Mainstreaming can also involve integrating multiple objectives into a single activity (e.g., biodiversity and development mainstreaming: IIED and UNEPWCMC, 2013).

Mainstreaming biodiversity was developed as a means of addressing the fact that biodiversity conservation goals are too often viewed as distinct from, and even in opposition to, the goals of development and economic growth. The higher priority put on development and economic prosperity means that investments in biodiversity conservation do not receive the political, social and financial support they need to succeed. Though mainstreaming has been referred to as "integrating" biodiversity into development, it is distinctly different in that it requires permanently modifying that into which it is integrated to ensure the persistence of biodiversity.

Mainstreaming is a term commonly used in the United Nations and other inter-governmental institutions and their associated treaty and implementation bodies, including those related to conservation. The concept of mainstreaming is, for example, included in article 6(b) of CBD, which calls on the Parties to the Convention to "integrate, as far as possible and as appropriate, the conservation and sustainable use of biological diversity into relevant sectoral or crosssectoral plans, programs, and policies" (CBD, 2003, p. 6). Mainstreaming also contributes toward fulfilling article 10(a), which calls on the Parties to "integrate consideration of the conservation and sustainable use of biological resources into national decision-making" (CBD, 2003, p.11). In addition, mainstreaming is called for in the Strategic Plan for Biodiversity 2011-2020 and its Aichi Targets. Target 6 on sustainable fisheries and Target 7 on sustainable agriculture and forestry have biodiversity mainstreaming implications and Targets 2 and 17 explicitly call for integration of biodiversity values into national planning through national biodiversity strategies and action plans (NBSAPs) and their adoption as policy instruments (Mapendembe et al., 2013; BirdLife and IUCN, 2015). 
Mainstreaming can focus at a number of different levelsfrom national policies to local plans to individual business practices, and from cross-cutting development plans such as poverty reduction strategies to sectoral policies such as agricultural growth or mineral extraction. Examples include:

1. National planning and development processes: Biodiversity targets and priorities must be integrated into national development planning frameworks and budgeting processes.

2. Sectoral policy and regulatory frameworks: It is vital to remove perverse subsidies and provide incentives for land and resource use that does not degrade biodiversity.

3. Land-use plans: Resource use practices must be appropriately situated to optimize production without degrading biodiversity.

4. Production and consumption practices: Production and consumption practices need to be changed so as to be more biodiversity friendly through adoption of sustainable production systems and reduced consumption.

5. Finance decision-making: Biodiversity standards and safeguards must be included in the funding decisions of international public financial institutions and private banks.

The term "mainstreaming" is little known in the conservation science community. Despite this, many of the practices or tools used by mainstreaming practitioners are well known in the conservation community, but just not labeled as mainstreaming. Table 1 lists some of these approaches such as payments for ecosystem services (PES), Reduced Emissions from Deforestation and Forest Degradation (REDD+) and environmental certification. Other approaches on the list are, however, less well known, and, overall, few in the conservation science community would recognize mainstreaming as an overarching practice that includes all these approaches.

\section{MAINSTREAMING IN PRACTICE}

With few exceptions, the very substantial investment by the GEF and others in mainstreaming projects is not reflected in the peer-reviewed literature (for an exception, South Africa: Cowling et al., 2008). Several reasons explain this including that mainstreaming projects rarely offer the opportunity to develop and test hypotheses because they are messy, highly context-dependent projects that often rely on the particularities of their implementers (Huntley, 2014). These characteristics, combined with the lack of broad engagement between conservation scientists and conservation implementers, the lack of requirement by funders to publish results of projects, and the apparent unfamiliarity with the vibrant field of practice, mean that the experience of implementing mainstreaming work is rarely analyzed and shared through formal channels. Instead it is to be found in the accounts of practitioners, in sessions at meetings, in numerous often difficult to locate project documents, websites and gray literature (c.f. BirdLife and IUCN, 2015: http://www.birdlife.org/datazone/info/mainstream).

In order to share some of the richness of the experience of mainstreaming practitioners, a GEF-STAP review commissioned a set of case studies (Huntley and Redford, 2014) that
TABLE 1 | Programs with objectives and approaches that are, or overlap with, biodiversity mainstreaming but do not use the term "mainstreaming" (details and references in Huntley and Redford, 2014).

Biodiversity offsets in general

Business and biodiversity offsets

The Equator Principles

Natural capital

Green Economy

Green Accounting; green growth

The Netherlands' program for ecological engineering, called "Building with Nature"

Agri-environmental schemes as practiced in the European Union

The hydropower industry's Hydropower Sustainability Assessment Protocol

The United Nations System of Environmental and Economic Accounts (SEEA), a system for organizing statistical data for the derivation of coherent indicators and descriptive statistics to monitor interactions between the economy and the environment and the state of the environment to better inform decision-making

The Wealth Accounting and the Valuation of Ecosystem Services (WAVES) program, a partnership which promotes sustainable development by ensuring that the national accounts used to measure and plan for economic growth include the value of natural resources

The Dow Jones Sustainability Index (DJSI) takes into consideration whether or not companies in some industries have processes in place to understand their impacts and dependencies on ecosystem services

The International Finance Corporation (IFC) evaluates due diligence based on a range of factors, including impacts and dependencies on ecosystem services

Seventy-eight global financial institutions referred to as Equator Banks are factoring ecosystem services impacts and dependencies into due diligence practices through programs and initiatives such as Biodiversity for Banks

Forty-one financial institutions, as well as the global Association of Chartered Certified Accountants (ACCA), have signed the Natural Capital Declaration to demonstrate commitment to the eventual integration of Natural Capital considerations into private sector reporting, accounting and decision-making, with standardization of measurement and disclosure of Natural Capital use by the private sector

are here complemented with three thumbnail sketches of mainstreaming projects by the authors that are designed to show the diversity of topics and settings where the work is taking place (see additional information and references in Table 2).

\section{Working for Water in South Africa}

South Africa's Working for Water program (WfW) represents one of the best documented case studies of biodiversity mainstreaming (Le Maitre et al., 2002; McConnachie et al., 2012, 2013). The stimulus for launching WfW arose from the convergence of four phenomena in the Cape region in the early 1990s (van Wilgen et al., 2002). These were (i) declining budgets 
TABLE 2 | Key lessons from mainstreaming case studies.

\begin{tabular}{ll}
\hline Case study & Key lessons \\
\hline Working for water in & - \\
South Africa & (employment of WfW's goals with political goals \\
of government \\
- Political goals invariably carry more weight and \\
often run counter to ecosystem \\
service/biodiversity goals \\
- Scientific proof of the concept of biodiversity \\
mainstreaming is essential \\
- Careful monitoring and evaluation is essential to \\
provide robust feedback to managers and to \\
counter their cognitive biases \\
- Champions who are good communicators and \\
strategically opportunistic are an absolute \\
prerequisite
\end{tabular}

Bioregional planning in South Africa

- In order to fully understand the opportunities and constraints for implementing bioregional plans, conduct comprehensive social assessments prior to conducting biophysical assessments (Knight et al., 2006; Cowling and Wilhelm-Rechmann, 2007; Knight et al., 2011)

- No single approach fits all; thus, identifying critical biodiversity features as priority areas is likely to work better in well-resourced regions whereas sites of cultural value may be more appropriate entities in poorly resourced communal lands (Wilhelm-Rechmann et al., 2014)

- The ongoing implementation of bioregional plans requires the establishment of learning organizations in each of their juristic regions, in order to facilitate social learning and adaptive management (Lombard et al., 2010; Knight et al., 2011)

Mainstreaming nature in Costa Rica
The focus of the program was on mainstreaming national strategies, policies and legislation on all aspects of invasive alien species management (a significant conservation problem in South Africa) with a focus on the control and removal of these plants from sensitive catchments to increase water yield and restore the biodiversity of wetland, riverine, fynbos, grassland and forest ecosystems. The objects of the mainstreaming included national catchment management authorities, local municipalities, private land-owners, and especially land conservancies.

The Working for Water project transformed policies and practice within the legislative (parliament, municipal by-laws), executive (agriculture, forestry, water management, and nature conservation), and private (industries, land owners, volunteer groups) sectors. For the first time, a national consciousness of, and active response to, the dangers of invasive alien species became embedded in all spheres of society.

The importance attached to the invasive alien species problem has led to a surge in conservation science investment in the field, placing South Africa among the leading centers of invasion biology. Mainstreaming resulted in the programs for rural employment and economic development. To date one million ha of invasive alien plants have been cleared and approximately 20,000 jobs and training opportunities per annum have been generated for the most economically marginal sector of the country's population (van Wilgen et al., 2012).

\section{Bioregional Planning in South Africa}

South Africa's bioregional planning program addresses the problem of retaining biodiversity in production landscapes. Using the principles and practices of systematic conservation assessment, bioregional plans have two key elements. First, a map of critical biodiversity areas, which are terrestrial and aquatic features critical for conserving biodiversity and maintaining ecosystem functioning, and which should thus remain in their natural state. Second, accompanying land-use guidelines for avoiding loss or degradation of natural habitat in critical biodiversity areas. The purpose of a bioregional plan is to inform all planning initiatives and environmental impact assessments of the location of priority biodiversity features that must be retained in the face of economic development.

The focus of the program was to mainstream bioregional planning into all local, provincial (state) and national entities involved in land use planning which are legally required to comply with the outcomes and recommendations of gazetted bioregional plans. Successful mainstreaming changed the practices of officials responsible for land use planning at all tiers of government; conservation agencies and NGOs for prioritizing areas requiring conservation actions; as well as consultants (mainly private sector) for environmental impact assessment.

The bioregional mainstreaming initiative has proved successful in that every South African municipality now has spatial biodiversity priorities and associated guidelines for land use that steer development away from priority areas (SANBI, 2014). In addition, the rate of transformation of conservation priority areas has slowed due to legal constraints and protected 
area targets for areas of high conservation value are increasingly being achieved.

\section{Mainstreaming Nature in Costa Rica}

The early stages of mainstreaming biodiversity and environment into national economic development in Costa Rica happened in an unplanned manner based primarily on economic factors, particularly the widespread benefits that ecotourism was bringing to the country. With one million tourists visiting Costa Rican National Parks today ecotourism generates more than $\$ 2.3$ billion annually with the benefits being spread broadly (Government of Costa Rica, 2011). This has created a solid base from which to advocate for broader governmental and societal responsibility for biodiversity conservation. The mainstreaming process began with ecotourism and was subsequently expanded to other areas and reinforced with policy reforms and incentives. First was the creation of the Forest Incentives program, which allowed landowners to benefit from forests without having to cut them down. In the early 1990's reforms phased out laws that promoted deforestation and production of crops for export. By the mid 1990 's policies promoting payment for environmental services (PES) became a major driver of social and environmental understanding and awareness [Universidad Nacional (Costa Rica), 2011].

The mainstreaming work focused on the policies and practices of the national Ministries of Environment, Agriculture, Planning and Finance that had approved a national sustainable development plan in response to the United Nations Sustainable Development Goals (Rodriguez, 2014). As a result of this process each Ministry developed specific environmental-related objectives. In turn environmental and biodiversity goals were no longer a specific task of the Ministry of Environment but rather a responsibility at the highest political level (President and Cabinet). These specific environmental responsibilities, based in the National Development Plan, required a sub-sectoral planning process and concrete deliverables to demonstrate societal accountability.

Currently the national financial mechanism pays for biodiversity and nature conservation with an annual budget of $\$ 30$ million and benefits more than 7000 individuals residing in designated biological corridors and other lands prioritized for their conservation benefits (Biodiversity Fund (Costa Rica), 2014). Planned new incentives and a potential green tax reform are being developed to fully engage the private sector (see also: http://www.worldbank.org/projects/P093384/mainstreamingmarket-based-instruments-environmental-managementproject?lang=en).

\section{A STRATEGIC OPPORTUNITY}

Almost seven billion dollars have been spent by the GEF and its partners on biodiversity mainstreaming between 2004 and 2014 (Huntley and Redford, 2014). This portfolio is complemented by work done by many other national, bilateral and multilateral organizations as well as businesses and trade associations. Yet few published, peer-reviewed studies have documented the nature and extent of this work and most of what is available is in unpublished project documents and the minds of practitioners.

The situation is ripe for informed coordination and creation of a science-driven field of biodiversity mainstreaming. Though a multitude of tools is beginning to be used, they are deployed either in different academic traditions with their own professional communities and journals, or by practitioners who do not often publish the results of their work or have not been properly evaluated (PES: Muradian et al., 2013; environmental certification: Milder et al., 2015). A new field could enfold these component pieces (e.g., Arkema et al., 2015), create the opportunity for bridging the doingknowing gap (Knight et al., 2008), create systems for lateral learning and develop robust measures of effectiveness. In addition to biodiversity conservation benefits such a new field could count on both funding and a supportive policy context. The GEF will continue to invest in mainstreaming, while the World Bank is currently supporting the Wealth Accounting and Valuation of Ecosystem Services (WAVES) partnership, focused on institutionalizing green accounting at the national level. Additionally, UNDP in October 2012 launched the Biodiversity Finance Initiative-BIOFIN-and is working in 29 countries to help mainstream biodiversity into national development and sectoral planning. Similarly, the Development Assistance Committee of the OECD is exploring how biodiversity conservation can be better mainstreamed into development assistance policy in support of the CBD (Drutschinin et al., 2015). Finally, a set of emerging, large, mainstreaming approaches are emerging (e.g., water funds; green infrastructure; large scale ecological restoration; and One Health initiatives that link human health and ecosystem condition) that would benefit from more careful attention by the conservation community.

There is an ample body of experience from which to begin careful analysis-for example the GEF alone has a repository of over 300 projects that offers an abundant potential source of learning through meta-analysis and synthesis. Also available to support the new field are recent reviews of experience to date (Petersen and Huntley, 2005; Cowling et al., 2008; IIED and UNEP-WCMC, 2013, 2014; GEF Independent Evaluation Office, 2014; Huntley and Redford, 2014; Drutschinin et al., 2015; SANBI et al., 2015) that provide some general advice for the policy communities. However, the lack of a formal written record emanating from mainstreaming projects (and many other conservation projects: Ferraro and Pattanayak, 2006) and the apparent absence of structured monitoring, learning, and evidence-generation limits the utility of the existing experience and makes even more urgent the need for a robust, analytical and coordinated approach that works across scales, geographies, approaches and institutions.

Yet despite these concerns, mainstreaming is being pursued around the globe with major funding creating a significant opportunity for the conservation science community to engage in a respectful, critical and helpful fashion. Much is at stake as shown in a recent analysis that demonstrates the potential 
power of mainstreaming to help mobilize from biodiversityrelevant sectors the financial resources necessary to achieve conservation goals for developing countries laid out in the Aichi targets (Kettunen et al., 2013). In order to maximize returns on the increasing investment in biodiversity mainstreaming as a conservation strategy, it is vital that all stakeholders collaborate in order to learn, innovate, and implement better practices so that biodiversity mainstreaming can become a robust, effective and recognized tool for conservation and sustainable development in the twenty-first century.

\section{REFERENCES}

Arkema, K. K., Verutes, G. M., Wood, S. A., Clarke-Samuels, C., Rosado, S., Canto, M., et al. (2015). Embedding ecosystem services in coastal planning leads to better outcomes for people and nature. Proc. Natl. Acad. Sci. U.S.A. 112, 7390-7395. doi: 10.1073/pnas.1406483112

Biodiversity Fund (Costa Rica) (2014). Internal Report. Fondo de Biodiversidad Costa Rica.

BirdLife and IUCN (2015). What Does Success Look Like? Mainstreaming Biodiversity. Available online at: http://www.birdlife.org/datazone/userfiles/file/ mainstreaming/Factsheet0_Ideas_IntroductionA\%20.pdf

Butchart, S. H. M., Walpole, M., Collen, B., van Strien, B., Scharlemann, J. P. W., Almond, R. E. A., et al. (2010). Global biodiversity: indicators of recent declines. Science 328, 1164-1168. doi: 10.1126/science. 1187512

CBD (2003). Handbook of the Convention on Biological Diversity, 2nd Edn. Montreal, QC: Convention on Biological Diversity.

Cowling, R. M., Egoh, B., Knight, A. T., O’Farrell, P., Reyers, B., Rouget, M., et al. (2008). An operational model for mainstreaming ecosystem services for implementation. Proc. Natl. Acad. Sci. U.S.A. 105, 9483-9488. doi: 10.1073/pnas.0706559105

Cowling, R. M., and Wilhelm-Rechmann, A. (2007). Social assessment as a key to conservation success. Oryx 41, 135-136. doi: 10.1017/S003065307001949

Drutschinin, A., Casado-Asensio, J., Roe, D., and Corfee-Morlot, J. (2015). Biodiversity and Development Cooperation. OECD Development Cooperation Working Papers. Paris: OECD Publishing. Available online at: http://www. oecd-ilibrary.org/development/biodiversity-and-development-co-operation_ 5js1sqkvts0v-en

Ferraro, P. J., and Pattanayak, S. K. (2006). Money for nothing? a call for empirical evaluation of biodiversity conservation investments. PLoS Biol. 4:e105. doi: 10.1371/journal.pbio.0040105

GEF Independent Evaluation Office (2014). OPS5. Fifth Overall Performance Study of the GEF. Final Report: At the Crossroads for Higher Impact. Washington, DC: Global Environment Facility.

Geldmann, J., Barnes, M., Coad, L., Craigie, I. D., Hockings, M., and Burgess, N. D. (2013). Effectiveness of terrestrial protected areas in reducing habitat loss and population declines. Biol. Conserv. 161, 230-238. doi: 10.1016/j.biocon.2013.02.018

Government of Costa Rica (2011). Ministry of Tourism, Tourism Strategic Plan 2012-2017. San Jose, CA: Government of Costa Rica, 113.

Hicks, R. L., Parks, B. C., Roberts, J. T., and Tierney, M. S. (2008). Greening Aid? Understanding the Environmental Impact of Development Assistance. New York, NY: Oxford University Press.

Huntley, B. J. (2014). Good news from the South: biodiversity mainstreaminga paradigm shift in conservation. S. Afr. J. Sci. 110, 1-4. doi: $10.1590 /$ sajs.2014/a0080

Huntley, B. J., and Redford, K. H. (2014). Mainstreaming Biodiversity in Practice: A STAP Advisory Document. Washington, DC: Global Environment Facility.

IIED and UNEP-WCMC (2013). Biodiversity and Development Mainstreaming. A State of Knowledge Review: Discussion Paper. IIED. Available online at: http:// pubs.iied.org/G03673.html

IIED and UNEP-WCMC (2014). "NBSAPs 2.0. mainstreaming biodiversity and development," in Third International Workshop (London, UK: IIED).

\section{AUTHOR CONTRIBUTIONS}

$\mathrm{KR}$ and $\mathrm{BH}$ conceived of paper based on workshop organized by $\mathrm{TH}, \mathrm{MZ}, \mathrm{GD}, \mathrm{KR}$ and BH. Case studies and additional writing by DR, CR, BH, and RC. Manuscript written by all authors.

\section{FUNDING}

Funding from the Scientific and Technical Advisory Panel of the GEF made possible the writing of this paper.

Kettunen, M., D’Amato, D., ten Brink, P., Mazza, L., Malou, A., and Withana, S. (2013). Potential of Sectoral Resource Mobilisation to Implement the Aichi Targets in Developing Countries. Brussels: Institute for European Environmental Policy (IEEP).

Knight, A. T., Cowling, R. M., Boshoff, A., Wilson, S. L., and Pierce, S. M. (2011). Walking in STEP: lessons for linking spatial prioritisations to implementation strategies. Biol. Conserv. 144, 202-211. doi: 10.1016/j.biocon.2010.08.017

Knight, A. T., Cowling, R. M., Rouget, M., Balmford, A., Lombard, A. T., and Campbell, B. M. (2008). Knowing but not doing: selecting priority conservation areas and the research-implementation gap. Conserv. Biol. 22, 610-617. doi: 10.1111/j.1523-1739.2008.00914.x

Knight, A. T., Driver, A., Cowling, R. M., Maze, K., Desmet, P. G., Lombard, A. T., et al. (2006). Designing systematic conservation assessments that promote effective implementation: best practice from South Africa. Conserv. Biol. 20, 739-750. doi: 10.1111/j.1523-1739.2006.00452.x

Le Maitre, D. C., van Wilgen, B. W., Gelderblom, C. M., Bailey, C., Chapman, R. A., and Nel, J. A. (2002). Invasive alien trees and water resources in South Africa: case studies of the costs and benefits of management. For. Ecol. Manag. 160, 143-159. doi: 10.1016/S0378-1127(01)00474-1

Lombard, A. T., Cowling, R. M., and Vlok, J. (2010). Designing conservation corridors in production landscapes: implementation issues and lessons learned. Ecol. Soc. 15, 7. Available online at: http://www.ecologyandsociety.org/vol15/ iss $3 /$ art7/

Mapendembe, A., Roe, D., and Bass, S. (2013). "NBSAPs 2.0: mainstreaming biodiversity and development," in Second International Workshop, IIED (London).

McConnachie, M. M., Cowling, R. M., Knight, A. T., and Shackleton, C. (2013). The challenges of alleviating poverty through ecological restoration: insights from South Africa's “Working for Water” programme. Restor. Ecol. 21, 544-550. doi: $10.1111 /$ rec. 12038

McConnachie, M. M., Cowling, R. M., van Wilgen, B. W., and McConnachie, D. A. (2012). Evaluating the cost-effectiveness of invasive plant removal: a case study from South Africa. Biol. Conserv. 155, 128-135. doi: 10.1016/j.biocon.2012.06.006

Milder, J. C., Arbuthnot, M., Blackman, A., Brooks, S. E., Giovannucci, D., Gross, L., et al. (2015). An agenda for assessing and improving conservation impacts of sustainability standards in tropical agriculture. Conserv. Biol. 29, 309-320. doi: 10.1111/cobi.12411

Miller, D. C. (2014). Explaining global patterns of international aid for linked biodiversity conservation and development. World Dev. 59, 341-359. doi: 10.1016/j.worlddev.2014.01.004

Muradian, R., Arsel, M., Pellegrini, L., Adaman, F., Aguilar, B., Agarwal, B., et al. (2013). Payments for ecosystem services and the fatal attraction of win-win solutions. Conserv. Lett. 6, 274-279. doi: 10.1111/j.1755-263X.2012. 00309.x

Petersen, C., and Huntley, B. (2005). Mainstreaming Biodiversity in Production Landscapes, Global Environment Facility Working Paper 20. Washington, DC: GEF.

Rodriguez, C. M. (2014). "Strengthening policy and regulatory frameworks at national and sub-national levels; advancing biodiversity-friendly policies and legislation and their implementation, supported by biodiversity-sensitive spatial planning and capacity building," in Mainstreaming Biodiversity in 
Practice: A STAP Advisory Document, eds B. J. Huntley and K. H. Redford (Washington, DC: Global Environment Facility), 59-60.

SANBI (2014). Biodiversity GIS. Available online at: http://bgis.sanbi.org/ municipalities/municipality.asp [Accessed December 17, 2014].

SANBI, GEF, and UNDP (2015). Mainstreaming Biodiversity. Key Principles from the Grasslands Programme. Available online at: http://biodiversityadvisor. sanbi.org/wp-content/uploads/2015/08/key-principles-in-mainstreamingbiodiversity-from-the-gp.pdf

Stolton, S., and Dudley, N. (2010). Vital Sites the Contribution of Protected Areas to Human Health. Research Report, WWF and Equilibrium Research. Available online at: http://www.iucn.org/about/work/programmes/gpap_home/ gpap_solutions/gpap_arguments/?11475/Vital-sites-- The-contributionof-protected-areas-to-Human-Health

Tscharntke, T., Clough, Y., Wanger, T. C., Jackson, L., Motzke, I., Perfecto, I., et al. (2012). Global food security, biodiversity conservation and the future of agricultural intensification. Biol. Conserv. 151, 53-59. doi: 10.1016/j.biocon. 2012.01.068

Universidad Nacional (Costa Rica) (2011). Auditoria Externa Programa de Pagos por Servicios Ambientales de FONAFIFO. Heredia: Editorial Unviersidad Nacional, 75.

van Wilgen, B. W., Forsyth, G. G., Le Maitre, D. C., Wannenburgh, A., Kotzé, J. D. F., van den Berg, E., et al. (2012). An assessment of the effectiveness of a large, national-scale invasive alien plant control strategy in South Africa. Biol. Conserv. 148, 28-38. doi: 10.1016/j.biocon.2011. 12.035 van Wilgen, B. W., Marais, C., Magadlela, D., Jezile, N., and Stevens, D. (2002). "Win-win-win: south africa's working for water programme," in Mainstreaming Biodiversity in Development: Case studies from South Africa, eds S. M. Pierce, R. M. Cowling, T. Sandwith, and K. McKinnon (Washington, DC: The World Bank), 5-20.

Watson, J. E. M., Dudley, N., Segan, D. B., and Hockings, M. (2014). The performance and potential of protected areas. Nature 515, 67-73. doi: 10.1038 /nature 13947

Wilhelm-Rechmann, A., Cowling, R. M., and Difford, M. (2014). Responses of South African land-use planning stakeholders to the new ecological paradigm and the inclusion of nature in self scales: assessment of their potential as components of social assessments for conservation projects. Biol. Conserv. 180, 206-213. doi: 10.1016/j.biocon.2014.10.012

Conflict of Interest Statement: The authors declare that the research was conducted in the absence of any commercial or financial relationships that could be construed as a potential conflict of interest.

Copyright $\odot 2015$ Redford, Huntley, Roe, Hammond, Zimsky, Lovejoy, da Fonseca, Rodriguez and Cowling. This is an open-access article distributed under the terms of the Creative Commons Attribution License (CC BY). The use, distribution or reproduction in other forums is permitted, provided the original author(s) or licensor are credited and that the original publication in this journal is cited, in accordance with accepted academic practice. No use, distribution or reproduction is permitted which does not comply with these terms. 